University of Nebraska - Lincoln

DigitalCommons@University of Nebraska - Lincoln

Agronomy \& Horticulture -- Faculty Publications

Agronomy and Horticulture Department

3-1-1992

\title{
In Situ Ruminal Protein Degradation of Switchgrass and Smooth Bromegrass
}

J. J. Mullahey

Southwest Florida Res. and Educ. Center, Immokalee, FL

Steven S. Waller

University of Nebraska-Lincoln, swaller1@unl.edu

K. J. Moore

USDA-ARS, kjmoore@iastate.edu

Lowell E. Moser

University of Nebraska-Lincoln, Imoser1@unl.edu

Terry J. Klopfenstein

University of Nebraska-Lincoln, tklopfenstein1@unl.edu

Follow this and additional works at: https://digitalcommons.unl.edu/agronomyfacpub

Part of the Plant Sciences Commons

Mullahey, J. J.; Waller, Steven S.; Moore, K. J.; Moser, Lowell E.; and Klopfenstein, Terry J., "In Situ Ruminal Protein Degradation of Switchgrass and Smooth Bromegrass" (1992). Agronomy \& Horticulture -- Faculty Publications. 76.

https://digitalcommons.unl.edu/agronomyfacpub/76

This Article is brought to you for free and open access by the Agronomy and Horticulture Department at DigitalCommons@University of Nebraska - Lincoln. It has been accepted for inclusion in Agronomy \& Horticulture -Faculty Publications by an authorized administrator of DigitalCommons@University of Nebraska - Lincoln. 


\title{
In Situ Ruminal Protein Degradation of Switchgrass and Smooth Bromegrass
}

\author{
J.J. Mullahey, S.S. Waller, ${ }^{*}$ K.J. Moore, L.E. Moser, and T.J. Klopfenstein
}

\begin{abstract}
Performance of livestock grazing warm-season, perennial grasses is generally greater than would be expected given their relatively low protein concentrations. Two experiments were conducted to assess ruminal escape protein using an in situ rumen technique for switchgrass (Panicum virgatum L.) and smooth bromegrass (Bromus inermis Leyss.). Whole-plant, leaf, and stem samples were harvested at specific stages of maturity in 1987. Duplicate samples of each grass were incubated for $12 \mathrm{~h}$ in situ. Escape protein values were expressed as concentration [grams escape protein per kilogram dry matter (DM) adjusted for acid detergent insoluble nitrogen (ADIN)] and as a percentage of total plant protein concentration (grams protein per kilogram DM adjusted for ADIN) to characterize protein composition. Whole-plant escape protein concentration was greater $(P<0.05)$ in switchgrass $\left(31.8 \mathrm{~g} \mathrm{~kg}^{-1} \mathrm{DM}\right)$ than smooth bromegrass $\left(22.3 \mathrm{~g} \mathrm{~kg}^{-1}\right.$ DM), averaged across all growth stages, and generally declined with maturity in both species. Escape protein concentration was consistently greater $(P<0.05)$ in leaves $\left(50.8 \mathrm{~g} \mathrm{~kg}^{-1} \mathrm{DM}\right)$ than in stems $\left(19.3 \mathrm{~g} \mathrm{~kg}^{-1} \mathrm{DM}\right)$ averaged over species and growth stages. As the proportion of stem to leaf increased during maturation, whole-plant escape protein concentration decreased. Escape protein percentage was similar for smooth bromegrass leaves and stems while switchgrass
\end{abstract}

J.J. Mullahey, Dep. Wildlife and Range Sci., Southwest Florida Res. and Educ. Center, Immokalee, FL 33934; S.S. Waller, Dep. of Agron., K.J. Moore, USDA-ARS, L.E. Moser, Dep. of Agron., T.J. Klopfenstein, Dep. Animal Sci., Univ. of Nebraska, Lincoln, NE 68583. Joint contribution of Nebraska Agric. Res. Div. and USDA-ARS, Journal series no. 9079. Received 20 May 1991. Corresponding author.

Published in Agron. J. 84:183-188 (1992). stems were generally higher than leaves. Escape protein percentage of whole-plant switchgrass $(50.9 \%)$ was greater $(P=0.08)$ than smooth bromegrass $(20.5 \%)$ over all harvest dates. Anatomical differences between switchgrass $\left(C_{4}\right)$ and smooth bromegrass $\left(C_{3}\right)$ may partially explain differences in ruminal protein degradation and subsequent animal performance.

$P$

ERFORMANCE OF LIVESTOCK grazing warm-season, perennial grasses is generally greater than would be expected given their relatively low protein and high fiber concentrations (Abrams et al., 1983; Reid et al., 1988). Ruminal microbial degradation of digestible protein in excess of microbial needs results in $\mathrm{N}$ loss as ammonia. Escape protein is dietary protein that is not degraded ruminally but is available for absorption in the small intestine. Provided there is adequate $\mathbf{N}$ for microbial growth, utilization can be more efficient when dietary protein is absorbed in the small intestine rather than when cycled through ruminal bacteria (Owens and Bergen, 1983). Higher than expected performance from warm-season grasses may be related to increased flow of undegraded protein to the lower gastrointestinal tract compared to cool-season grasses.

Leaf proteins of warm- $\left(\mathrm{C}_{4}\right)$ and cool-season $\left(\mathrm{C}_{3}\right)$ grasses differ in composition and concentration be-

Abbreviations: ADF, acid detergent fiber; ADIN, acid detergent insoluble nitrogen; $C P$, crude protein; DM, dry matter; and RuBPCase, ribulose-1,5-bisphosphate carboxylase. 
cause of differences in photosynthetic pathways between the two types of grasses. In warm-season grasses, Calvin cycle enzymes are localized within parenchyma bundle sheath cells that are relatively resistant to microbial degradation when compared with similar tissues in cool-season species (Akin, 1989). Ku et al. (1979) reported that 8 to $23 \%$ of total soluble protein in warm-season species is ribulose-1,5-bisphosphate carboxylase (RuBPCase). In contrast, RuBPCase comprises 25 to $60 \%$ of the total soluble protein in cool-season grasses and is located in both mesophyll and bundle sheath cells of these species. We have hypothesized that RuBPCase and other enzymes localized within the bundle sheath cells of warm-season grasses may escape rumen degradation and pass intact to the lower tract because they are physically protected from degradation.

Objectives of our research were to (i) characterize seasonal patterns of escape protein of whole-plant, leaf, and stem fractions of smooth bromegrass (Bromus inermis Leyss.) and switchgrass (Panicum virgatum L.) and to (ii) quantify the relationship between in situ rumen degradable protein and crude protein (CP) for both species.

\section{MATERIALS AND METHODS}

\section{Sample Collection and Preparation}

Experimental selections from 'Pathfinder' switchgrass and 'Lincoln' smooth bromegrass were collected from separate nurseries at the University of Nebraska Agricultural Research and Development Center near Mead, NE in 1987. Nurseries were located on a Sharpsburg silty clay loam soil (fine, montmorillonitic, mesic Typic Argiudolls). Smooth bromegrass $(5$ by $13 \mathrm{~m}$ ) and switchgrass plots $(40$ by 45 $\mathrm{m})$ were located randomly within three field replications. Both nurseries were burned in late March to remove standing dead material. Smooth bromegrass and switchgrass nurseries were fertilized with $121 \mathrm{~kg} \mathrm{~N} \mathrm{ha}^{-1}$ in late April and late May, respectively. Smooth bromegrass sampling was initiated on 4 June 1987 (seedhead), approximately $60 \mathrm{~d}$ after greenup. Switchgrass plots were clipped on 4 June 1987 to remove the standing crop and sampling began 29 June. The harvest strategy was designed to produce similar growth stages during the summer, thereby minimizing confounding effects of phenology and environment. Approximately $25 \mathrm{~kg}$ (fresh weight) was harvested from each plot at each date using a sicklebar mower. Plant sampling continued through September for both species to characterize summer forage.

Harvested material was frozen in insulated coolers with dry ice and stored at $-20^{\circ} \mathrm{C}$. Subsamples were lyophilized, ground (2-mm screen), and composited over field replicates because of limited animal numbers available for in situ analysis. Total plant $\mathrm{N}$ was determined using a Kjeldahl procedure (AOAC, 1975) and CP was calculated by multiplying total $\mathrm{N}$ by a factor of 6.25 .

\section{In Situ Methodology}

A modification of the in situ technique reported by Anderson et al. (1988) was used. Preliminary experiments conducted with smooth bromegrass and switchgrass forage indicated that the acid detergent fiber (ADF) bag used by Anderson et al. (1988) to estimate microbial attachment increased variability of escape protein estimates. Unadjusted values and values adjusted for ADIN improved precision (Mullahey, 1989). Therefore, the ADF adjustment technique described by Anderson et al. (1988) to estimate microbial $\mathbf{N}$ was eliminated from our procedure.

Escape protein was calculated as total residual $\mathrm{N}$ remaining following a 12-h incubation adjusted for ADIN (the indigestible $\mathrm{N}$ fraction) using the following equations:

$$
\begin{aligned}
& \begin{array}{c}
\text { Escape Protein } \\
\left(\mathrm{g} \mathrm{kg}^{-1} \mathrm{DM}\right)
\end{array}=6.25(\text { Total Residual } \mathrm{N}-\text { ADIN }) \\
& \text { Escape Protein }=\frac{\text { Total Residual } \mathrm{N}-\text { ADIN }}{\text { Total Plant } \mathrm{N}-\text { ADIN }} \times 100 \\
& \text { Percentage }
\end{aligned}
$$

Escape protein concentration is indicative of the amount of nutritionally useful forage escape protein available to the small intestine. Amount of escape protein is not always directly related to plant $\mathrm{CP}$ concentration. Escape protein percentage characterizes the plant protein composition.

\section{Whole-Plant Study}

Forage was harvested based on phenology and staged using the system described by Moore et al. (1991). Smooth bromegrass harvest $(2.5-\mathrm{cm}$ stubble height) dates were 4 June (first-growth, R3), 15 July (regrowth, E2), 19 August (regrowth, E5), and 24 September (regrowth, E7). Harvest dates for switchgrass (6-cm stubble height) were 29 June (V3), 22 July (R0), 19 August (S1), and 24 September (S4).

A ruminally-fistulated Angus $\times$ Hereford steer $(250 \mathrm{~kg})$ was fed a diet of big bluestem (Andropogon gerardii Vitman) and smooth bromegrass hay $(50: 50 ; \mathrm{CP}=10 \%$, IVDMD $=58 \%$ ) at $2 \%$ of body weight. The diet supported a weight gain of $0.13 \mathrm{~kg} \mathrm{~d}^{-1}$ for the donor steer. Approximately one-half of the diet was fed at $0800 \mathrm{~h}$ with the remaining portion fed at $2000 \mathrm{~h}$. Diets were fed at least 7 $\mathrm{d}$ prior to the in situ experiment.

Duplicate dacron in situ bags $(5$ by $8.8 \mathrm{~cm})$ with a pore size of 35 to $80 \mu \mathrm{m}$ (Haik's Inc., Springfield, MO) were provided for each species and harvest data. A 1.5-g forage sample was placed in each bag and the bag sewn shut. Duplicate forage bags were included for each species and harvest date. Bags were attached to a metal chain and presoaked in $40^{\circ} \mathrm{C}$ tap water for $5 \mathrm{~min}$. All bags were then placed into the ventral sac of the rumen at $0800 \mathrm{~h}$ and removed as a group at $2000 \mathrm{~h}$. Following removal bags were rinsed in $40^{\circ} \mathrm{C}$ running tap water for $2 \mathrm{~h}$ with occasional agitation until the rinse water was clear (no discoloration or ruminal debris). Each bag was frozen and subsequently analyzed for Kjeldahl $\mathbf{N}$. The experiment was repeated using the same donor steer (block).

Duplicates within a block were averaged and data were analyzed as a nested split-plot design. Whole plots consisted of species and the subplots were harvest dates within species. The response to date of harvest within species was separated using a protected LSD (Steel and Torrie, 1980).

\section{Leaf-Stem Study}

Smooth bromegrass was clipped $(2.5-\mathrm{cm}$ stubble height) on 4 June (first-growth, R3), 15 July (regrowth, E2), 31 July (regrowth, E3), 19 August (regrowth, E4) and 24 September (regrowth, E7). Switchgrass was harvested $(15-\mathrm{cm}$ stubble height) on 15 July (E2), 24 July (R0), 9 August (R3), 19 August (S1), and 24 September (S4) Forage was separated into leaf and stem fractions before incubation in situ. The in situ assay was conducted similarly to the previous experiment except that $5-\mathrm{g}$ forage samples and 10.5by $23-\mathrm{cm}$ dacron bags $(35-80 \mu \mathrm{m}$ pore size) were used. The larger bag and sample was calculated to have the same sample size to bag surface area as in the whole-plant experiment. Sample size was increased to provide material for additional studies. Each bag was sealed by wrapping the top around a no. 8 rubber stopper and securing with a 
no. 18 rubber band. The bag was then folded over the rubber band and a second rubber band added (Wilkerson and Klopfenstein, 1991). To allow more efficient rinsing, bags were not sewn shut in this experiment (Wilkerson et al., 1990). Bags were confined inside a nylon mesh bag and placed inside the ventral sac of a donor steer for a 12$\mathrm{h}$ incubation. Bags were placed in a nylon bag rather than attached to a metal chain to minimize stratification effects within the rumen.

The rinse procedure varied from the whole-plant study to ensure more complete removal of adhered rumen particulate material from the exterior and interior of each bag. Bags were opened and $40^{\circ} \mathrm{C}$ rinse water was added $(4 \mathrm{~L}$ min $^{-1}$ ) to the interior of the bag; this process was continued until the rinse water was clear. Following 24-h drying in a $60^{\circ} \mathrm{C}$ forced air oven, bags were weighed and the residue was ground to pass through a cyclone mill equipped with a 1-mm screen, and analyzed for total $N$.

The experimental design was a nested split-split-plot design. Whole plots consisted of species (two) and subplots were harvest dates (five) nested within species and sub-sub plots were plant parts (two). Samples from each treatment were incubated in two animals (blocks). The experiment was replicated twice over a 2 -d period. Duplicates were averaged. Data analysis was performed using GLM procedures (SAS, 1982). The response to date of harvest within species was separated using a protected LSD (Steel and Torrie, 1980).

\section{In Situ Ruminal Degradable Protein and Crude Protein}

The relationship between rumen degradable protein and forage CP concentration was determined to estimate relative differences in microbial attachment between switchgrass and smooth bromegrass forage. Rumen degradable protein was expressed as a percentage of plant protein calculated by difference from percentage of escape protein. The leaf and stem fractions at several stages of maturity provided a wide range in CP (40 observations per species). Regressions of rumen degradable protein on CP were calculated and compared using simple linear regression techniques described by Steel and Torrie (1980).

\section{RESULTS AND DISCUSSION}

\section{Whole-Plant Study}

Total plant CP concentration was generally less for switchgrass (76.9 $\mathrm{g} \mathrm{kg}^{-1} \mathrm{DM}$ ) compared to smooth bromegrass (111.2 $\left.\mathrm{g} \mathrm{kg}^{-1} \mathrm{DM}\right)$ when averaged over dates. This relationship was consistent at comparable growth stages (Fig. 1). Smooth bromegrass CP concentration decreased from 23 to $13 \% \mathrm{DM}$ on a wholeplant basis while switchgrass decreased from 19 to 6\% with maturity. Escape protein concentration was greater $(P<0.05)$ in switchgrass $\left(31.8 \mathrm{~g} \mathrm{~kg}^{-1} \mathrm{DM}\right)$ than smooth bromegrass $\left(22.3 \mathrm{~g} \mathrm{~kg}^{-1} \mathrm{DM}\right)$, averaged over all growth stages. In switchgrass, the escape protein concentration was greatest $(P<0.05)$ in young, vegetative (V3) plants (June) and declined with maturity (Fig. 2). Smooth bromegrass escape protein concentration was also greatest $(P<0.05)$ for the most immature growth stage (regrowth, E2). At the last harvest date, both species had similar escape protein concentrations.

Switchgrass whole-plant samples had greater $(P=$ $0.08)$ escape protein percentage $(50.9 \%)$ than smooth bromegrass $(20.5 \%)$, averaged over all growth stages

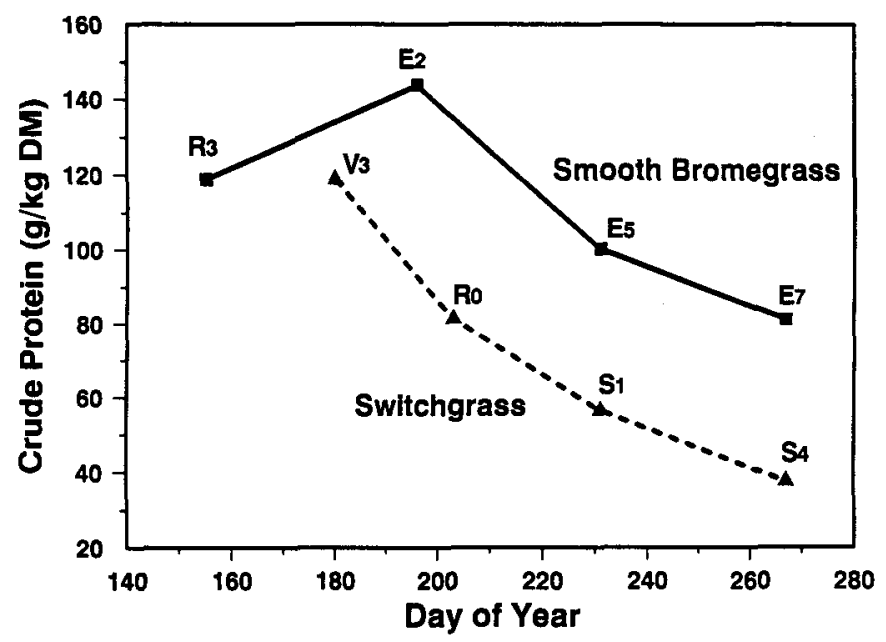

Fig. 1. Patterns of crude protein concentration for composite whole plant samples of smooth brome and switchgrass collected at selected growth stages during the 1987 growing season at Mead, NE.

(Fig. 3). Escape protein percentage increased $(P<$ $0.05)$ in switchgrass as plants matured between the boot stage (R0) and seed ripe (S4) while it remained relatively constant $(P>0.05)$ in smooth bromegrass. The highest escape protein percentage for switchgrass was $70.1 \%$ at the seed ripe growth stage. Similar trends in crude protein and escape protein concentration for both species and divergent trends in escape protein percentage suggested that there were disproportionate changes in rumen degradable protein.

\section{Leaf-Stem Study}

Total CP concentration generally declined with maturity and was consistently greater for leaves than stems at comparable growth stages, averaged over species (Fig. 4). Smooth bromegrass and switchgrass leaves and stems had similar $\mathrm{CP}$ concentrations during the study with the exception of the last harvest date. Crude

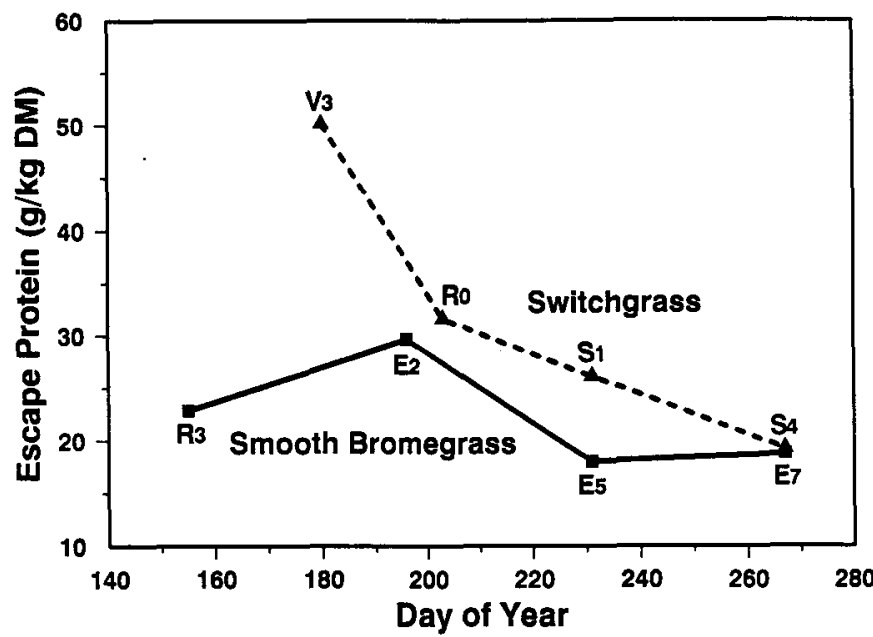

Fig. 2. Escape protein concentration ( $\mathrm{kg}^{-1} \mathrm{DM}$ ) for composite whole plant samples of smooth brome and switchgrass collected at selected growth stages during the 1987 growing season at Mead, NE. 


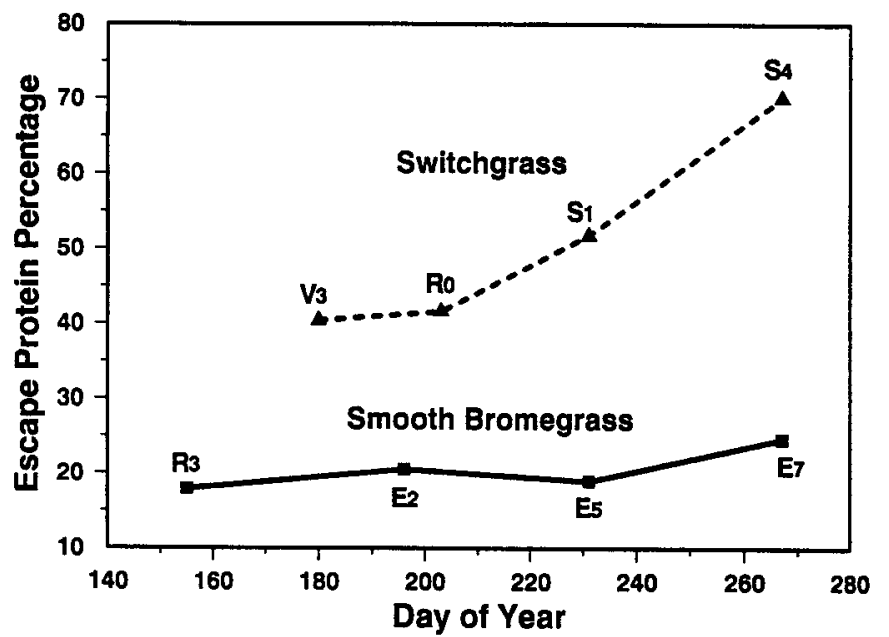

Fig. 3. Escape protein percentage for composite whole plant samples of smooth brome and switchgrass collected at selected growth stages during the 1987 growing season at Mead, $\mathbf{N E}$.

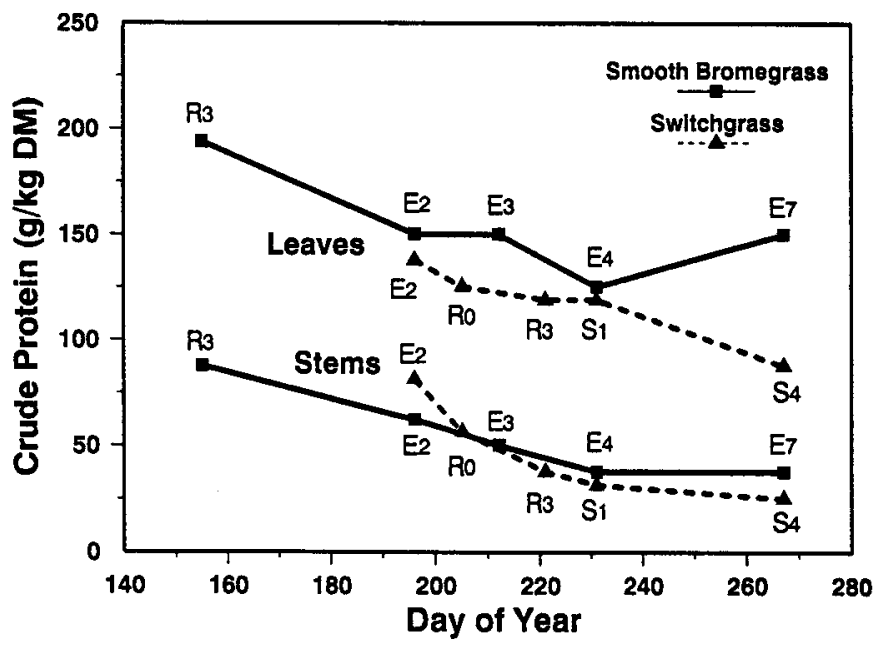

Fig. 4. Patterns of crude protein concentration for composite leaf and stem samples of smooth brome and switchgrass collected at selected growth stages during the 1987 growing season at Mead, NE.

protein concentration of smooth bromegrass leaves generally increased while switchgrass leaves continued to decline with advancing growth stage. This was apparently a response to improved environmental conditions for smooth bromegrass growth during the fall.

For smooth bromegrass, escape protein concentration in leaves was consistently greater than in stems (Fig. 5). The response of escape protein concentration to growth stage was not consistent between plant parts $(P=0.06)$. Excluding the 4 June harvest date for stems, escape protein concentration tended to increase slightly with advancing growth stage. Greater escape protein concentration values occurred at later harvests for leaves, while the greatest concentration for stems occurred at the 4 June harvest (first growth, seedhead). Escape protein percentage was similar for smooth bromegrass leaves and stems at each harvest date (Fig. 6). Escape protein percentage generally increased slightly with advancing maturity in both leaves and stems.

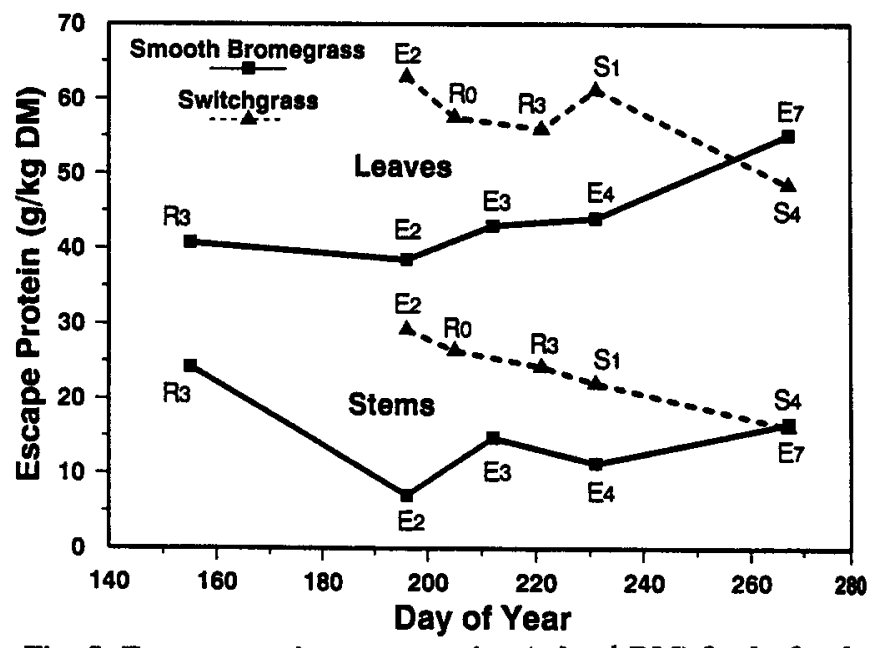

Fig. 5. Escape protein concentration ( $\mathrm{g}^{-1} \mathrm{DM}$ ) for leaf and stem samples of smooth brome and switchgrass collected at selected growth stages during the 1987 growing season at Mead, NE.

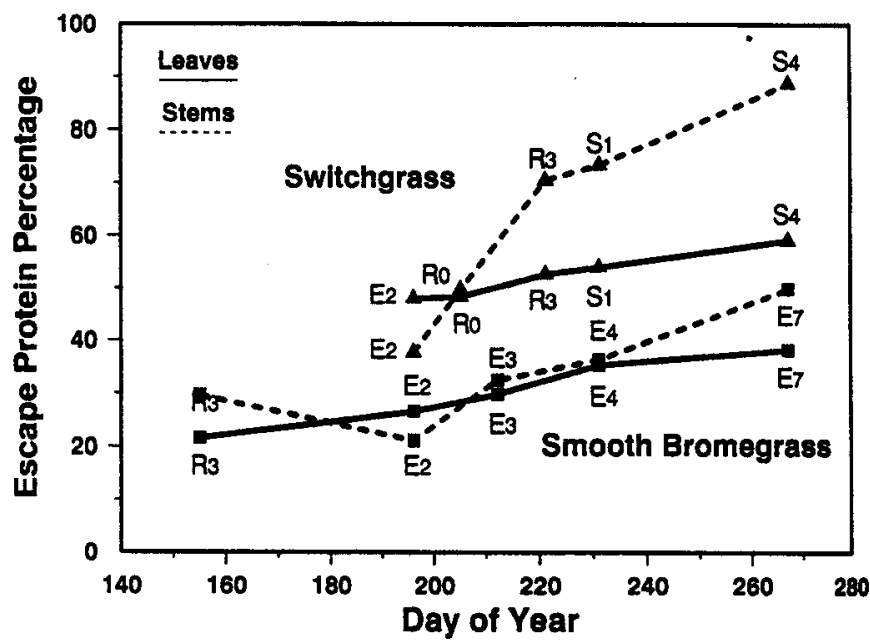

Fig. 6. Escape protein percentage for leaf and stem samples of smooth brome and switchgrass collected at selected growth stages during the 1987 growing season at Mead, NE.

For switchgrass, the response of escape protein concentration (Fig. 5) was not consistent within plant part $(P=0.06)$. Leaves consistently had greater escape protein concentrations than stems at each date. Unlike smooth bromegrass, leaf and stem escape protein concentration decreased linearly with advancing maturity. By the end of the growing season, escape protein concentration for smooth bromegrass (E7) and switchgrass (S4) leaves and stems was similar.

Although escape protein percentage increased linearly with date for both leaves and stems of switchgrass, an interaction occurred due to stem escape protein percentage increasing at a faster rate than leaf escape protein (Fig. 6). Escape protein percentage was greater in the stems than the leaves for the last three dates. This suggested that the change in protein composition of the stem was very dynamic with advancing maturity.

The general trend of declining escape protein con- 
centration and increasing escape protein percentage in switchgrass plant parts as they matured apparently reflected faster declines in leaf and stem CP concentrations. However, the patterns for smooth bromegrass leaf and stem CP concentration and escape protein concentration were similar. This resulted in very little change in the escape protein percentage over the harvest dates (Fig. 6).

Although plant phenology was different between switchgrass and smooth bromegrass, differences in the pattern and magnitude of response suggested there were differences in escape protein concentration and escape protein percentage. Generally, switchgrass leaves and stems had greater numerical values for escape protein concentration than smooth bromegrass. Escape protein percentage was higher in switchgrass for both leaves and stems compared with smooth bromegrass. Possibly anatomical differences between switchgrass $\left(\mathrm{C}_{4}\right)$ and smooth bromegrass $\left(\mathrm{C}_{3}\right.$; i.e. bundle sheath cells and lignified parenchyma) may partially explain differences in ruminal protein degradation. Escape protein concentration values were always less in stems than leaves, so as the proportion of stem to leaf (DM basis) increased during maturation, forage concentration of escape protein declined.

\section{In Situ Ruminal Degradable Protein and Crude Protein}

The relationship between ruminally degradable protein and CP of leaves and stems was examined for both species. Theoretically, the relationship between ruminally degradable protein and CP should be linear, with the slope equal to true ruminal degradability coefficient and intercept equal to microbial attachment to plant fiber. This assumes the latter entity is constant and, in this system, represents microbial attachment to forage fiber.

Based upon regression analysis, smooth bromegrass CP was $29 \%$ more degradable $(P<0.05)$ than switchgrass CP (Fig. 7). Conversely, $43 \%$ of the CP in switchgrass escaped in situ degradation compared to $26 \%$ for smooth bromegrass. Microbial attachment was relatively low for both species and was not different from zero $(P<0.05)$. Based on this analysis, the overall contribution of microbial matter to residual DM was considered negligible. However, these values should be considered relative since microbial attachment may not be consistent over the range of $\mathrm{CP}$, plant parts, and fiber contents used in this research.

\section{CONCLUSIONS}

Whole-plant CP concentration was higher for smooth bromegrass than switchgrass at each harvest date and declined with advancing maturity. This same pattern was maintained for both leaf and stem fractions, with leaves having higher levels of $\mathrm{CP}$ concentration than stems. Both species had measurable levels of escape protein concentration. Switchgrass escape protein concentration (whole-plant, leaf and stem) generally declined with maturity while smooth bromegrass was stable to increasing with fall growth. However, switchgrass generally had higher escape protein concentration for whole-plant, leaf and stem compared to

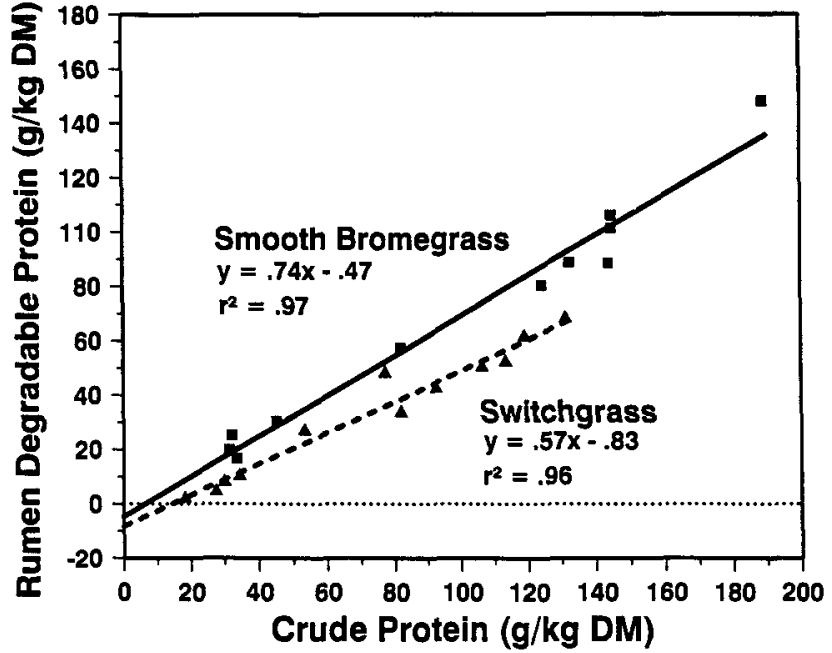

Fig. 7. Relationship between ruminally degradable protein and CP for switchgrass and smooth brome. Values for leaf and stem fractions at several stages of maturity were used to develop the relationship. Standard errors of the slope $\left(S_{b}\right)$ and intercept $\left(S_{a}\right)$ were 0.041 and 0.733 for smooth brome and 0.037 and 0.973 for switchgrass, respectively.

smooth bromegrass. Escape protein concentration was consistently greater in leaves than stems for both species, but stems generally had a greater percentage of escape protein. Since CP was less for switchgrass and the decline with maturity more severe than smooth bromegrass, escape protein percentage was consistently greater for switchgrass than smooth bromegrass. Changes in leaf-stem ratio appeared to have a significant impact on whole-plant escape protein concentration for both species. Smooth bromegrass management resulted in a higher leaf-to-stem ratio compared to switchgrass which probably increased whole-plant escape protein concentration. Differences would be expected to be as great or greater if the species could be compared at equivalent phenological stages. Apparent differences in escape protein concentration between the cool- and warm-season grasses used in this study may partially explain the inconsistency between CP levels and animal performance on warm-season grass pastures.

\section{REFERENCES}

Abrams, S.M., H. Hartadi, C.M. Chaves, J.E. Moore, and W.R. Ocumpaugh. 1983. Relationship of forage-evaluation techniques to the intake and digestibility of tropical grasses. p. 508511. In J.A. Smith and V.W. Hays (ed.) Proc. International Grassland Congress, 14th, Lexington, KY. 15-24 June 1981. Westview Press, Boulder, CO.

Akin, D.E. 1989. Histological and physical factors affecting digestibility of forages. Agron. J. 81:17-25.

Anderson, S.J., T.J. Klopfenstein, and V.A. Wilkerson. 1988. Escape protein supplementation of yearling steers grazing smooth brome pastures. J. Anim. Sci. 66:237-242.

Association of Official Analytical Chemists. 1975. Official methods of analysis (12 Ed.) AOAC. Washington, DC.

Ku, M.S.B., M.R. Schmitt, and G.E. Edwards. 1979. Ouantitative determination of RuBP carboxylase-oxygenase protein in leaves of several $C_{3}$ and $C_{4}$ plants. J. Exp. Bot. 30:89-98.

Moore, K.J., L.E. Moser, K.P. Vogel, S.S. Waller, B.E. Johnson, and J.F. Pedersen. 1991. Describing and quantifying growth stages of perennial forage grasses. Agron. J. 83:1073-1077

Mullahey, J.J. 1989. Influence of management on production, development, and protein utilization of warm-season grasses. Ph.D. diss. Univ. of Nebraska, Lincoln (Diss. Abstr. 90-13617). 
Owens, F.N., and W.G. Bergen. 1983. Nitrogen metabolism of ruminant animals: historical perspectives, current understanding and future implications. J. Anim. Sci. 57(Suppl. 2):498-518. SAS. 1982. SAS user's guide: Statistics. SAS Inst., Inc., Cary, NC.

Reid, R.L., G.A. Jung, and W.V. Thayne. 1988. Relationships between nutritive quality and fiber components of cool season and warm season forages: a retrospective study. J. Anim. Sci. 66:1275-1291.
Steel, R.G.D., and J.H. Torrie. 1980. Principles and procedures of statistics (2nd Ed.) McGraw-Hill Book Co., New York.

Wilkerson, V.A., S.M. Hannah, R.C. Cochran, and T.J. Klopfenstein. 1990.' Rinsing procedure for in situ protein degradation as influenced by technician and method. J. Anim. Sci. 68(Suppl. 1):517 (Abstr.)

Wilkerson, V.A., and T.J. Klopfenstein. 1991. Collaborative study of in situ forage protein degradation. p. 99-102. In Proc. 199 Forage and Grassland Conf., Columbia, MO. 1-4 April 1991. Amer. Forage and Grassl. Council, Georgetown, TX. 